\title{
ANALYSIS OF WATER AWARENESS, ACCOUNTABILITY, AND GOVERNANCE TO IMPROVE SUSTAINABILITY OF FIRM'S PERFORMANCE IN URBAN AREAS
}

DOI: $10.21163 / \mathrm{GT} \_2020.151 .04$

\author{
Agustine DWIANIKA ${ }^{1}$ (D), Etty MURWANINGSARI ${ }^{2,}$, Wayan SUPARTA ${ }^{3}$ (i)
}

\begin{abstract}
:
Managing water efficiency will cut costs and promote the environment and increase public awareness of the importance of water in governance. Water conflicts and the increasing phenomenon of water scarcity will result in business stagnation, especially for sustainable firm's performance. The purpose of this research is to find a new measurement model to improve the sustainability of a firm's performance through awareness of water and environmental management. This study was conducted on 20 manufacturing firms in Indonesia where 100 respondents were taken from the firm. The questionnaire was used as a tool to collect data on water awareness, accountability awareness, and water governance. Explanatory research is also carried out to analyze the effect of these three variables on the sustainability of firm performance. The results showed that water awareness, accountability awareness and corporate governance by the measurement of the ASEAN Corporate Governance (CG) Scorecard supported firm performance. This result can be recommended to improve the firm's sustainability performance, especially in urban areas.
\end{abstract}

Keywords: Water awareness, Accoutability awareness, ASEAN CG Corecard, Sustainable Firm's Perfomance

\section{INTRODUCTION}

According to the World Resources Institute (WRI), Indonesia is one of the countries expected to experience water stress in 2040 as shown in Fig. 1. This is partly due to a lack of awareness of tree planting, the use of water for households is increasing, exploration and use of water for industrial, especially manufacturing. Recent research on the problem of water in various regions has been observed by Biocchi et al. (2015) and Boutera et al. (2012). Climate change such as heat waves also plays an important role in influencing water availability especially in urban areas (Suparta \& Yatim, 2019).

Due to the lack of land capacity to absorb water due to reduced forest area and rainwater absorption, good corporate governance now plays an important role in the possibility of accounting fraud and companies that have weak governance structures are becoming more vulnerable to fraud (Brigham et al., 2009). Company performance can be achieved by enhancing an organizational culture that can be done by applying the principles of Good Corporate Governance (GCG). One of the rankings of corporate governance is to

\footnotetext{
${ }^{1}$ Universitas Pembangunan Jaya, Accounting Department, Jl. Cendrawasih Raya Block B7 / P, Sawah Baru, Ciputat, Tangerang Selatan, Banten 15413, Corresponding author: agustine.dwianika@upj.ac.id

2 Trisakti Universiti, Accounting Department, Jl. Kyai Tapa, Grogol, Jakarta Barat 11440 Indonesia,etty_nasser@yahoo.com

3 Universitas Pembangunan Jaya, Department of Informatics, South Tangerang City, Banten 15413, Indonesia, Corresponding author: wayan.suparta@upj.ac.id
} 
use the ASEAN Corporate Governance Scorecard. This ranking is often used as a measurement of Corporate Governance practices. This refers to the provisions of the ASEAN Capital Market Forum (ACMF) as an association of ASEAN capital market authorities. The ASEAN Corporate Governance Scorecard is based on the OECD Principles and will increase the investor's trust to public companies (Globe Telecom, 2019).

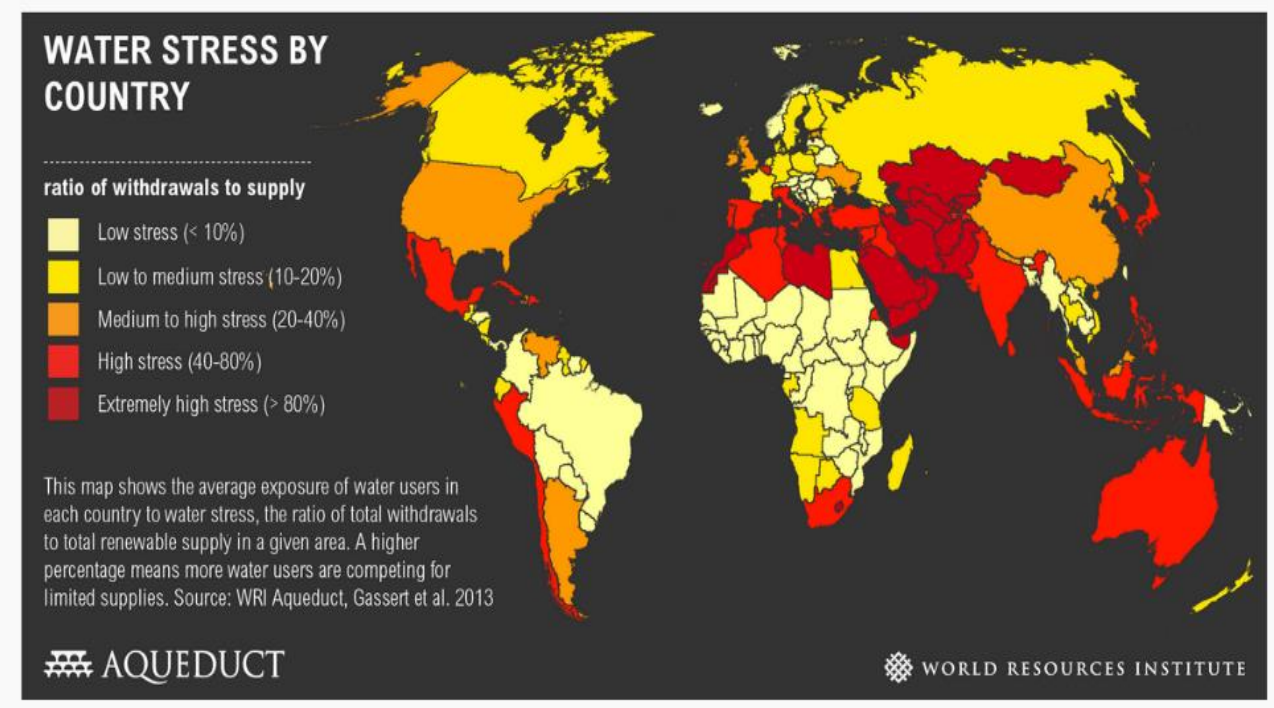

Fig. 1. Water stress by country where Indonesia is in high stress level (WRI Aqueduct, 2013).

Awareness of the preservation of natural resources for the next generation has become an international concern, especially highlighting water exploration for the manufacturing sector in the production process. In countries facing water shortages, water conservation education is one of the targets at the school level. By introducing the program to students about the importance of water conservation and economic value, it will increase awareness among the community to know that a good percentage of people are students (Gilley et al., 2006). At present, water awareness and accountability are widely studied and linked to water accounting systems for water management strategies. One of them is the framework of the water accounting system as stated by Turner et al. (2010).

The recent financial crisis is creating new or recent emphasis on risk management which is important for financial and non-financial companies. For many companies, the focus on risk management is still a new thing, and they found the right place to start is to identify and manage strategic risk companies; risk the most impact on the organization's ability to execute its strategy and achieve its goals. Richard et al. (2009) identified 207 different performance variables from 213 reviewed articles from 2006 to 2009. They stated that the performance of the organization consists of the actual output of an organization as measured against its intended output, which includes three specific areas, namely corporate results profitability, return on assets (ROA) and return on equity (ROE). However, a recent study intensively looks at the company's performance is not only financial but also nonfinancial. Kaplan and Norton (2004), shows that non-financial performance measures are a better indicator of future financial performance. 
The objective of this research is to find a new measurement model to improve the sustainability of company performance through water and environmental management. Therefore the relationship between water awareness and accounting awareness is expected to influence the implementation of the ASEAN CG Scorecard company and have a positive impact on company performance. Awareness of water sustainability is very important to be motivated to increase stakeholder control over the application of good governance.

\section{METHODS}

This study uses the population of all companies listed in the Indonesia Stock Exchange (ISE) in 2017 which publishes the Financial Statements. Samples were obtained by using a purposive sampling method with the criterion of manufacturing companies listed in ISE in 2017. This sample is considered to use water resources which are relatively large compared to other types of companies and are located in an urban area. To recommend the firm's performance to achieve water sustainability, variable used to be analyzed in this research are water awareness refers to ten indicators belonging to Jawad (2012), accounting awareness refers to seven indicators of Turner et al. (2010), and Firm's Governance refers to the measurement of ASEAN CG Scorecard. The expected output is the firm's performance refers to Kotane (2012). The expected model developed in this study is using the multiple linear regression (MLR) method as shown in the following equation.

$$
\mathrm{Y}=\alpha+\beta_{1} \mathrm{X}_{1}+\beta_{2} \mathrm{X}_{2}+\beta_{3} \mathrm{X}_{3}+\varepsilon
$$

where $\alpha, \beta_{1}, \beta_{2}$, and $\beta_{3}$ are constant, while $X_{1}$ is the water awareness, $X_{2}$ is the accounting awareness and $X_{3}$ is the corporate governance. The output $Y$ is firm's performance. The three constants are obtained by ANOVA (Analysis of Variance) approach. Besides using MLR equation, explanatory research is also used to explain the effect of three variables on the firm's performance.

Fig. 2 shows the research process in obtaining an adoption model. The first step will design measurement tools for data collection. Secondly, the instrument developed will be tested and validated, analyzed and discussed. For the validation and to test the reliability of the instrument, Cronbach Alpha is employed. Cronbach's alpha is a measure of internal consistency that is how closely a set of items is correlated with other items as a group. An SPSS 25 software is employed to analyze the three variables above. This study used 100 respondents to representing 20 manufacturers firm In Indonesia as shown in Fig. 3 which cover Java and Kalimantan Islands. Each firm is represented by five respondents which are one respondent at the top level of managerial, two respondents as middle level, and two respondents as junior staff. The criteria for selecting respondents are employees in corresponding positions in sample firms with a minimum working period is one year.

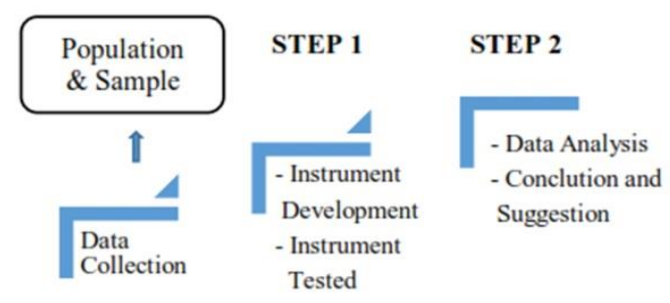

Fig. 2. Research Process in determining water sustainability to firm's performance. 


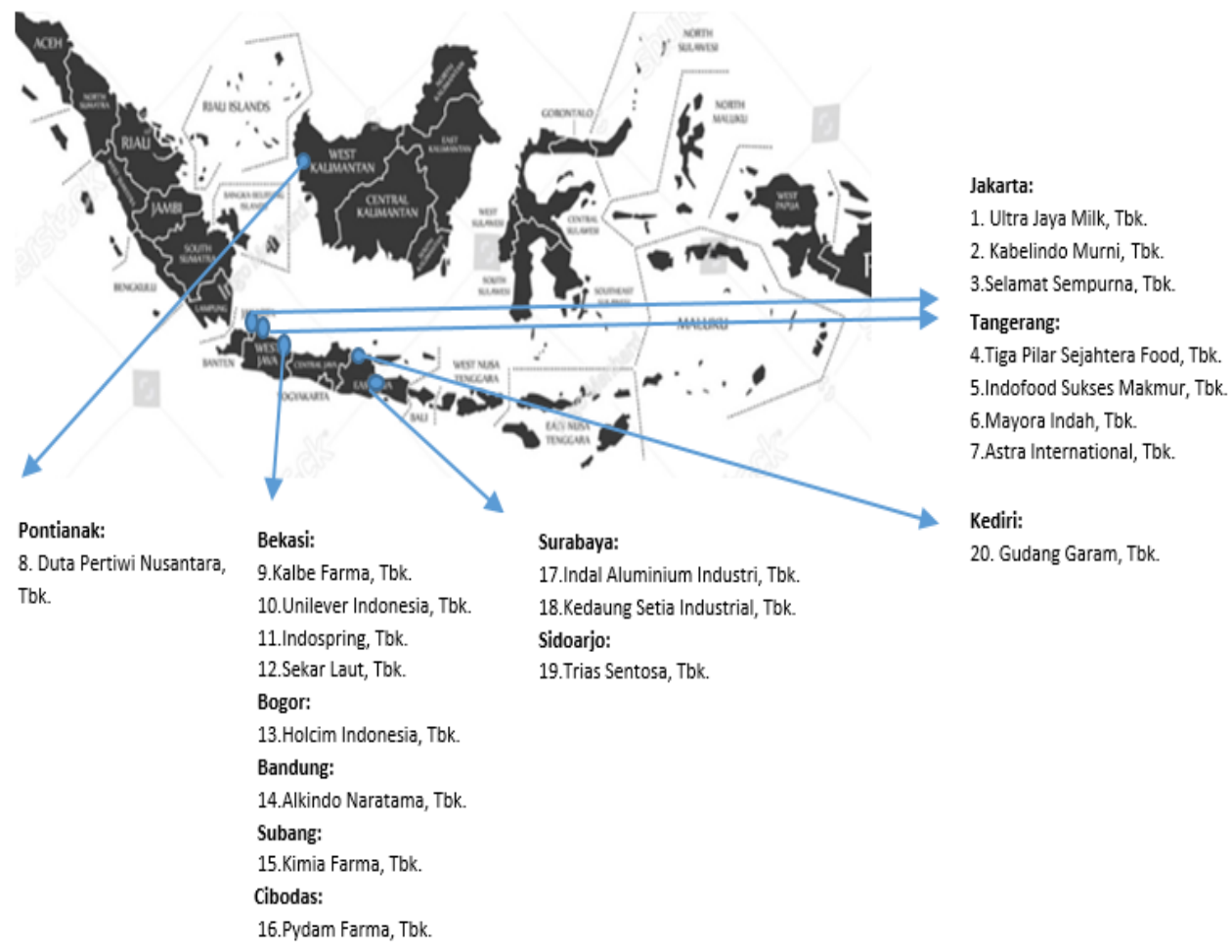

Fig. 3. Firm's study case location in Indonesia.

\section{RESULT AND DISCUSSION}

From the data obtained, several test data analysis was conducted. Initial analyzes related to the demographic data of respondents such as gender, education level, age and the length of the respondents working with companies in the sample showed an ascending trend. Most of the respondents are male as much as $70 \%$ as shown in Table 1. It is very reasonable considering the company sample is manufacturing, which does have a tendency to take longer to work without a lot of distractions and allow to work overtime.

The respondent demographic showed that the level of education are $15 \%$ certificated, $15 \%$ diplomas , $65 \%$ degrees, and $5 \%$ postgraduates. Note that the manufacturing business selected as a sample is likely more focused on human resources which have a good working experience compared to the high level of education. The majority of respondents aged between 35-44 (55\%), 45-54 (20\%), 25-34 (15\%), and the last age of the respondents is above $55(10 \%)$. While the mayority of finance department employee is aged between 35-44 years old, where this age is an ideal for a productive performance. A $60 \%$ of respondents have worked at the company between 6-10 years, above 10 years, and the last is 1-5 years. In ifdeal organization, expertise employees can minimize the errors that occur 
in the company's business processes, especially in terms of financial reporting by using water awareness adoption.

Table 1.

Demography for 100 Respondens.

\begin{tabular}{|l|l|r|r|}
\hline & Gender & Frequency & Percent \\
\cline { 2 - 4 } & Male & 70 & $70 \%$ \\
& Female & 30 & $30 \%$ \\
\hline Age & $25-34$ & 15 & $5 \%$ \\
& $35-44$ & 55 & $55 \%$ \\
& $45-54$ & 20 & $20 \%$ \\
& $>=55$ & 10 & $10 \%$ \\
\hline Domicile & Jakarta & 20 & $20 \%$ \\
& Bogor & 25 & $25 \%$ \\
& Depok & 16 & $16 \%$ \\
& Tangerang & 32 & $32 \%$ \\
& Bekasi & 7 & $7 \%$ \\
\hline \multirow{5}{*}{ Level of education } & Certified & 15 & $15 \%$ \\
& Diploma & 15 & $15 \%$ \\
& Degree & 65 & $65 \%$ \\
& Post Graduate & 5 & $5 \%$ \\
\hline & $>10$ years & 35 & $35 \%$ \\
\hline & $6-10$ years & 60 & $60 \%$ \\
\hline & $1-5$ years & 5 & $5 \%$ \\
\hline
\end{tabular}

Source: SPSS Data (2019)

To test the instrument developed, 20 respondents is used as a pilot study to indicate the measuring instrument developed (questionnaire) is valid. The result for this validity test for each variable is presented in Table 2. The result shows the consistency of the variable tested with a reliability value (Cronbach's Alpha) of 0.750 . The results also showed the value of the coefficient of determination Adjusted R Square (R2) is approximately 0.492. This means that $49.2 \%$ of non-financial performance was influenced by the sample companies studied and the rest is possibly by other factors.

Table 2.

The Validity Test with $\mathbf{N}=20$.

\begin{tabular}{|c|c|c|c|c|}
\hline No. & Variable & $\mathrm{r}^{\text {count }}$ & $\mathrm{r}^{\text {table }}$ & Remark \\
\hline 1 & Water Awareness & 0.514 & 0.360 & valid \\
\hline 2 & Accounting Awareness & 0.527 & 0.360 & valid \\
\hline 3 & Corporate Governance & 0.511 & 0.360 & valid \\
\hline 4 & Firm's Performance & 0.553 & 0.360 & valid \\
\hline
\end{tabular}

The pilot test result show consistency and reliably of measurement with moderate correlation and then 100 respondents now is used to collect data for data analysis to produce a model as shown in Table 3. The correlation ( $\left.\mathrm{r}^{\text {count }}\right)$ between items and the total items show a stronger correlation with $\mathrm{r}$ above 0.7 except for Water Awareness.

To ascertain the value of the influence of the three variables, the MLR test is carried out using 100 data that have been collected where the results are shown in Table 4. This important step is intended to test the hypothesis that water awareness and accountability will influence the implementation of the ASEAN CG Scorecard and its impact on the firm's performance. The results of this test are illustrated in Table 5. The table shows that 
the $\mathrm{F}$ test was 5,096 to 0.001 lower than 0.05 . This means the hypothesis is accepted where the three variables are a very clear influence on the firm's performance.

\section{Table 3.}

The Validity Test with $\mathrm{N}=100$.

\begin{tabular}{|c|l|c|c|c|}
\hline No. & \multicolumn{1}{|c|}{ Variable } & $\mathrm{r}^{\text {count }}$ & $\mathrm{r}^{\text {table }}$ & Remark \\
\hline 1 & Water Awareness (WA) & 0.627 & 0.165 & valid \\
\hline 2 & Accounting Awareness (AA) & 0.726 & 0.165 & valid \\
\hline 3 & Corporate Governance (CG) & 0.856 & 0.165 & valid \\
\hline 4 & Firm's Performance (Y) & 0.859 & 0.165 & valid \\
\hline
\end{tabular}

Tabel 4.

The result of Multi Linier Regression (MLR) Coefficient $^{\mathrm{a}}$

\begin{tabular}{|cl|r|r|r|r|}
\hline & Model & \multicolumn{1}{c|}{$\begin{array}{c}\text { Unstandardized } \\
\text { Coefficients }\end{array}$} & $\begin{array}{c}\text { Standardized } \\
\text { Coefficients }\end{array}$ & F & Sig. \\
\hline 1 & Constant & 3673.623 & 576.380 & 2.976 & 0.000 \\
& WA & 125.482 & 159.161 & 0.215 & 0.001 \\
& AA & 629.105 & 117.550 & 1.015 & 0.000 \\
& CG & 567.225 & 221.026 & 4.966 & 0.001 \\
\hline
\end{tabular}

a. Dependendent Firm's Performance

Tabel 5.

F Statistical Test Result from ANOVA ${ }^{a}$

\begin{tabular}{|l|l|r|r|r|r|r|r|}
\hline \multicolumn{2}{|l|}{ Model } & Sum of Squares & df & $\begin{array}{c}\text { mean } \\
\text { Square }\end{array}$ & F & $\begin{array}{c}\text { F } \\
\text { Table }\end{array}$ & Sig. \\
\hline \multirow{3}{*}{1} & Regression & 1.634 & 4 & 0.408 & 5.096 & 2.724 & $0.001^{\mathrm{b}}$ \\
\cline { 2 - 9 } & residual & 2.805 & 35 & 0.080 & & & \\
\cline { 2 - 9 } & Total & 4.438 & 39 & & & & \\
\hline
\end{tabular}

${ }^{a}$ Dependent Variable: Company Performance

${ }^{\mathrm{b}}$ Predictors: (Constant), Water Awareness, Awareness Accounting, Corporate Governance

From Table 4, the equation's value obtained from equation can be formulated as below.

$$
\mathrm{Y}=3.673,623+125,482 \mathrm{WA}+629,105 \mathrm{AA}+567,225 \mathrm{CG}
$$

It shows that three variables effect on Firm's Performance. WA affects 9.5\%, AA affects $47.59 \%$ and $\mathrm{CG}$ affects $42.91 \%$. The contribution of these parameters can be illustrated as in Fig. 4. Results about water awareness, accoutability awareness and corporate governance on firm's performance showed a significance of $0.047<0.05$. This means that the hypoteses tested is accepted. 
(a)

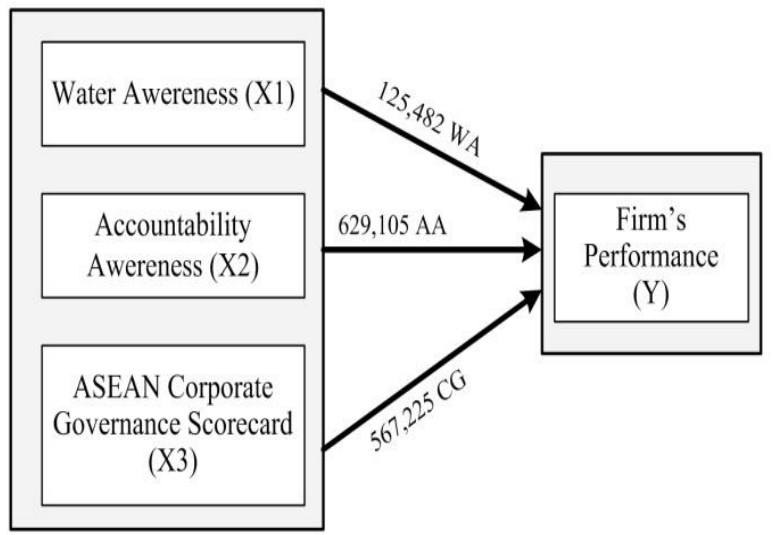

(b) Coefficient of Each Variable

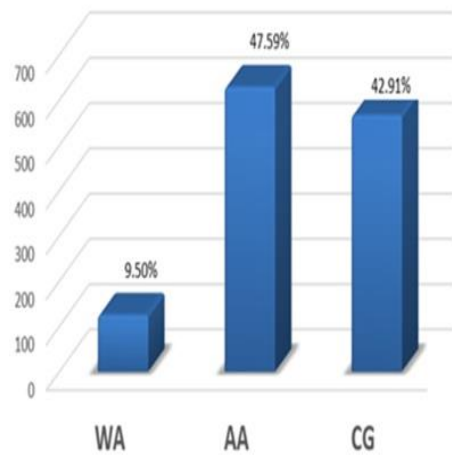

Fig. 4. (a) the influence of three variables on the Firm's Performance and (b) the percentage influence in each variable

\section{CONCLUSIONS}

In general, the manufacture firms listed on the ISE have water awareness. They also count this awareness on reporting corporate governance to gain the firm's sustainability. The result indicates that each variable significantly influences on Sustainability Firm's performance. Water awareness, accountability awareness, and corporate governance showed a positively correlation to increase the firm's performance. According to this finding, this research contributes to suggest new measurement of Firm's Sustainability Performance by considering water and accountability awareness. Manufacturing firms are suggested to adopt this model by applying water-based governance principles.

Further research to improve the measurement of sustainability performance has been identified by comparing the results with other sectors and experiences from other countries. The contribution of water awareness is moderately correlated for this case, however, in larger and more complex urban areas, it is important to expand the scope of the research area.

\section{ACKNOWLEDGMENTS}

The award, speeches, and high appreciation we conveyed to the Director of the LP2M Universitas Pembangunan Jaya for giving us the trust and provided funding to conduct research. Thank you also to Accounting students from Pembangunan Jaya University who helped distribute the questionnaire.

\section{R E F E R E N C E S}

ACCA 2010 Disclosures on water. Accountants for Business. http:// www.accaglobal.com/sustainabilityreporting

Water Supply Regulatory Agency of Jakarta 2018 Jakarta drinking water crisis. http://www.brpamdki.org

Baiocchi, V., Lelo, K. \& Vatore, F. 2015 Boolean logic model for an environmental protection plan on a local administration terriotry. Geographia Technica, 10, 2/2015, pp 1-8. 
Brigham, Eugen F. and Joel F. Houston. 2009. Fundamentals of Financial Management. Jakarta: Four Salemba.

Boutera, M., Roubhia, A., Lakheneche, D. \& Xeereg, S. 2012 Wastewater rejection impact on groundwater wuality in a semi arid region. Case of Tebessa Aquifer. Geography Technica, 1, 19-27.

Freeman, RE 2004. A Stakeholder Theory of Modern Corporations. Ethical Theory and Business, 7th edn.

Gilley, R., Sullivan, R., Tang, S. \& Tarbet, A., 2006. Water Conservation in Windhoek Schools, City of Windhoek: The Department of Infrastructure, Water and Technical Services.

Globe Telecom 2019 ASEAN Corporate Governance Scorecard. https://www.globe.com.ph/aboutus/corporate-governance/asean-corporate-governance-scorecard.html.

Gujarati, D. 2003. Basic Econometrics. Jakarta: Erland.

Jawad A. D. 2012 Water issues and accounting awareness. American Journal of Scientific Research 60, 46-53, http://www.eurojournals.com/ajsr.html,

Jensen, M. C. \& William, H. M.1976 Theory of the Firm: Managerial Behavior, Agency Costs, and Ownership Structure. Journal of Financial Economics, 3, 305-360.

Kotane, I. \& Merlino 2012 Non financial indicator for evaluation of business activity. Riga International School of Economics and Business Administration. DOI 10.5755/j01.eis.0.5.1099.

Richard, P. J., Devinney, T. M., Yip, G. S. \& Johnson, G. 2009 Measuring ORGANIZATIONAL PERFORMANCE: TOWARDS BEST PRACTICE methodological. Journal of Management, $35,3,718-804$.

Suparta, W. \& Yatim, A. N. M. 2019 Characterization af heat waves: a case study for Peninsular Malaysia. Geographia Technica, 14 (1), 146 - 155.

Turner, G., Baynes, T. M., McInnis, B.C. 2010 A Water accounting system for strategic water management. Water Resouces Management Journal. DOI: 10.1007/s11269-009-9457-7.

Wiersma, E. 2008 An exploratory study of the relative and incremental information content of two non-financial performance measures: Field study evidence of absence on frequency and on-time delivery. Accounting, Organizations and Society, 33, 249-265. 